\title{
Ideal-observer models of perceptual contrast enhancement
}

\author{
Jonathan Platkiewicz ${ }^{1 *}$, Hannah Michalska², Vincent Hayward ${ }^{1}$ \\ From Twenty Second Annual Computational Neuroscience Meeting: CNS*2013 \\ Paris, France. 13-18 July 2013
}

In standard ideal-observer models of sensory cue integration [1], the perceptual estimate resulting from the combination of two cues lies in the interval bounded by the estimates of each cue separately. For example, this type of model accounts well for the psychophysical result - observers give an estimate in-between the haptic-alone and the visual-alone estimates, when asked to estimate ridges height with both vision and touch [2]. Nevertheless, a class of perceptual illusion is supposedly not accounted for by this type of model, namely contrast illusion, such as the size-weight illusion [3,4]. In the size-weight illusion, when asked to estimate the weight of two objects of the same mass but not the same size, observers estimate the larger as lighter. Using standard ideal-observer models, we showed that it is possible to account for this class of illusion provided that statistical correlation between each cue estimate is taken into account. Our argument is based on statistical inference models such as linear minimumvariance unbiased estimation, maximum a posteriori estimation, and least relative surprise estimation. This psychophysical model is general as long as the perceptual estimate deals with a physical quantity that is proportional to another physical quantity also available as a cue, such as mass and volume for a given material in the size-weight illusion.

\section{Acknowledgements \\ We thank Marc Ernst and Cesare Valerio Parise for fruitful discussions. This work was supported by the European Research Council (FP7 Programme) ERC Advanced Grant agreement no. 247300.}

\section{Author details}

'Institut des Systèmes Intelligents et de Robotique, UPMC Univ Paris 06, Paris, France. ${ }^{2}$ Department of Electrical and Computer Engineering, McGill University, Montreal, Quebec, H3A 2A7, Canada.

\footnotetext{
* Correspondence: platkiewicz@isir.upmc.fr

${ }^{1}$ Institut des Systèmes Intelligents et de Robotique, UPMC Univ Paris 06, Paris, France

Full list of author information is available at the end of the article
}

Published: 8 July 2013

\section{References}

1. Trommershäuser J, Körding KP, Landy MS: Sensory cue integration New York: Oxford University Press; 2011

2. Ernst MO, Banks MS: Humans integrate visual and haptic information in a statistically optimal fashion. Nature 2002, 415:429-433.

3. Ernst MO: Perceptual learning: inverting the size-weight illusion. Current Biol 2009, 19:23-25.

4. Brayanov JB, Smith MA: Bayesian and "anti-Bayesian" biases in sensory integration for action and perception in the size-weight illusion. J Neurophysiol 2010, 103:1518-1531.

doi:10.1186/1471-2202-14-S1-P162

Cite this article as: Platkiewicz et al: Ideal-observer models of perceptual contrast enhancement. BMC Neuroscience 2013 14(Suppl 1): P162.

Submit your next manuscript to BioMed Central and take full advantage of:

- Convenient online submission

- Thorough peer review

- No space constraints or color figure charges

- Immediate publication on acceptance

- Inclusion in PubMed, CAS, Scopus and Google Scholar

- Research which is freely available for redistribution

Submit your manuscript at www.biomedcentral.com/submit

\section{() Biomed Central}

\section{Biomed Central}

